\title{
Assessment of PNGV Fuels Infrastructure: Infrastructure Concerns Related to the Safety of Alternative Fuels
}

by Steven E. Plotkin

Center for Transportation Research, Energy Systems Division,

Argonne National Laboratory, 9700 South Cass Avenue, Argonne, Illinois 60439

June 2000

Work sponsored by the United States Department of Energy,

Assistant Secretary for Energy Efficiency and Renewable Energy,

Office of Transportation Technologies 
This report is printed on recycled paper. 


\section{Contents}

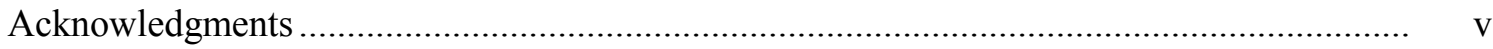

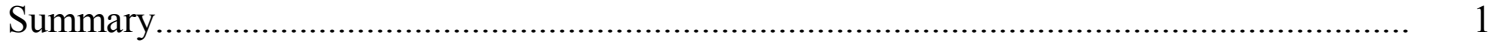

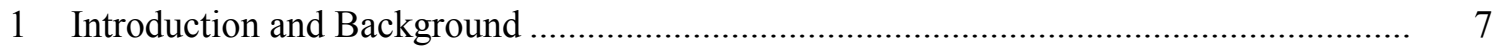

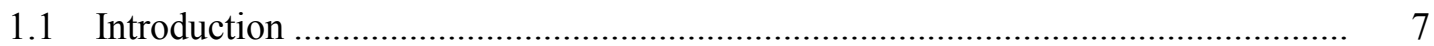

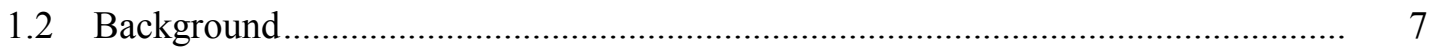

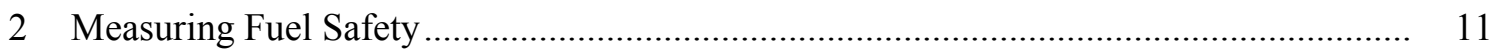

2.1 Physical/Chemical Characteristics ............................................................... 12

2.1.1 Properties Affecting the Likelihood of Spills or Releases ......................... 12

2.1.2 Properties Affecting the Threat to Human Health and Environment after a Release ........................................................... 12

2.1.3 Properties Affecting Fire and Explosion Danger after a Fuel Release ...................................................................... 13

2.2 Other Factors with Safety Implications ........................................................... 14

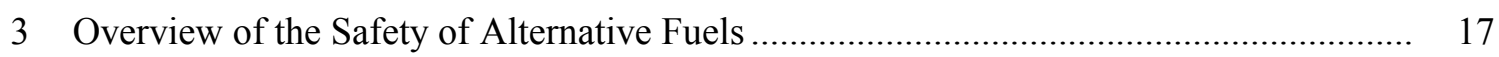

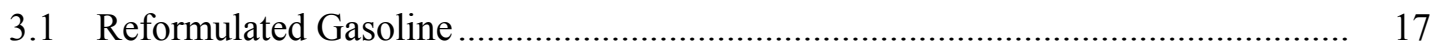

3.2 Diesel Fuel — RFD, Biodiesel, F-T Diesel....................................................... 18

3.3 Dimethyl Ether.......................................................................... 19

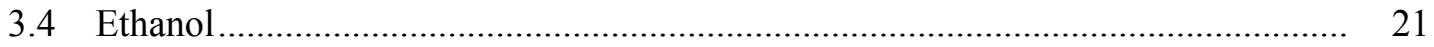

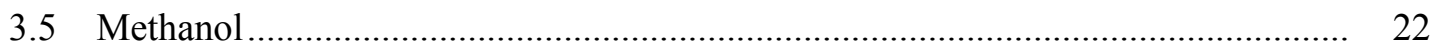

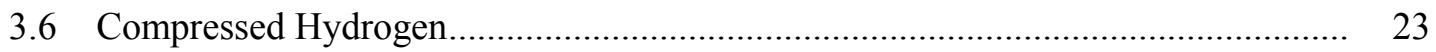

4 Infrastructure Issues Associated with Fuel Safety Concerns.......................................... 27

4.1 Alternative Fuel Volumes Relative to Current

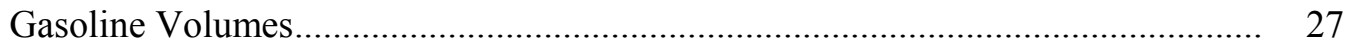

4.2 Speed of Market Introduction of Alternative Fuels ................................................ 28

4.3 Volume of Alternative Fuels Relative to Current Hazardous Materials Shipments ............................................................................... 29

4.4 Impact on Hazardous Material Emergency Response

4.5 Firefighting Issues for Alternative Fuels Versus Gasoline....................................... 31

4.6 Maintenance and Repair of Alternative-Fuel Vehicles Versus
Conventional Vehicles..................................................................................... 32 
4.7 Storage of Alternative Fuels and Vehicles .......................................................... 33

4.7.1 Home Garages .................................................................................... 33

4.7.2 Refueling Stations ................................................................................. 33

4.8 Spills and Contamination of Drinking Water Supplies ....................................... 34

4.9 Monitoring of Safety Incidents Involving Alternative Fuels............................... 34

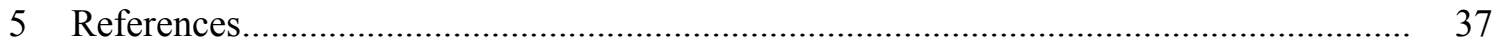

\section{Tables}

1 Important Safety-Related Characteristics of Alternative Fuels.................................... 15

2 Energy Densities of Alternative PNGV Fuels for Light-Duty Vehicles ....................... 28 


\section{Acknowledgments}

The author would like to acknowledge the careful reviews and constructive comments of Richard Bechtold, QSS Group; Peter Machiele, U.S. Environmental Protection Agency; and Marianne Mintz, Argonne National Laboratory. 
$\Delta$ 


\section{Summary}

\section{S.1 Overview}

This study examines infrastructure requirements and concerns associated with fuel safety, assuming that new fuels are introduced into the light-duty-vehicle (LDV) marketplace by the large-scale production of " $3 \mathrm{X}$ vehicles" — vehicles attaining three times the fuel economy of today's vehicles — under the Partnership for a New Generation of Vehicles (PNGV). The maximum-penetration scenario examined assumes that $3 X$ vehicles enter the market in 2007 and capture a $60 \%$ share of the new LDV market by 2030 . The case of all the $3 \mathrm{X}$ vehicles using a single new fuel and the case of a variety of new fuels being introduced are both of interest in defining potential concerns about infrastructure.

The baseline fuel is assumed to be federal Phase 2 reformulated gasoline (RFG). The new fuels are:

- Reformulated diesel, RFD;

- Fischer-Tropsch diesel, F-T;

- Biodiesel;

- Dimethyl ether, DME;

- Methanol;

- Ethanol; and

- Compressed hydrogen.

Vehicle technologies include hybrid drivetrains powered by direct-injection, spark-ignited or compression-ignited engines and by fuel cells. Safety, in the context of this report, encompasses the following: fire and explosion hazards associated with fuel leaks, vehicle collisions, and large fuel spills; human exposure to toxic materials associated with spills or direct contact with the fuels; and contamination of water or land from spills. Safety issues associated with damage from slow leaks are excluded. The scope of our concern includes the whole fuel cycle, although we focus on the downstream portion of the cycle (e.g., fuel storage and transport to service stations, refueling, vehicle operation, and vehicle maintenance and repair).

This study is not about whether one fuel is more dangerous than another. We note, however, that gasoline is a highly flammable and toxic fuel and that fuel safety analysis is a complex and subjective task. 


\section{S.2 Infrastructure concerns}

The use of gasoline in light-duty motor vehicles raises important safety concerns. Gasoline is a highly flammable liquid, the vapor of which, being heavier than air, can travel some distance from an actual spill and ignite if it meets an open flame or a spark. If ingested and aspirated into the lungs, small quantities of gasoline can be fatal. In 1986, gasoline was the first material to ignite in 180,000 vehicle fires, causing nearly 800 deaths, over 4,000 serious injuries, and over \$200 million in property damage. This information shows that new transportation fuels, no matter what their dangers, will not replace a benign fuel.

Nevertheless, PNGV planners and others should be concerned about safety issues should large quantities of new fuels enter the marketplace. Gasoline is a well-established fuel; the industry and users have 100 years of widespread experience in fuel system design, infrastructure development, and handling and use. However, new fuels - regardless of their relative safety have different physical characteristics and safety risks, and every part of the fuel handling system will have to be adjusted to accommodate these differences. Because safety analysis is not an exact science, and because it is unlikely that a new system can be put into place without making some mistakes, there will inevitably be a transition period during which safety problems will be aggravated. Also, the nature of both the news media and the legal system virtually guarantees that a spotlight will be focused on real and imagined safety issues associated with new fuels. One concern is the potential for the media to illuminate (and perhaps exaggerate) safety concerns; another is the potential for litigators to sue automakers and others who could be held liable for any injuries tied to the new fuels. The auto industry would benefit by taking all reasonable, available measures to prepare for the fuels transition and to minimize its impact on public safety.

Important infrastructure concerns associated with the safety of new fuels include the following:

\section{Is a monitoring and evaluation system in place that can quickly identify and respond to safety problems arising from new fuels?}

Short answer: To our knowledge, the capability of the current fuel safety monitoring and evaluation system has not been systematically examined. It would be prudent to undertake such an examination before introducing large volumes of alternative fuels.

Discussion: Key players in identifying and evaluating fuel safety problems are the U.S. Department of Transportation's (DOT's) Research and Special Programs Administration for fuel spills during transport (incident reporting is required under federal law) and the DOT's Office of Defects Investigation of the National Highway Traffic Safety Administration (NHTSA) for problems with vehicle fuel systems. Organizations representing fleet managers, gas station owners, and others would presumably also play a role in identifying problems. Reports to NHTSA should come from the National Fire Incident Reporting System (NFIRS), which is run by the U.S. Fire Administration; the NHTSA auto safety hotline; and the Fatal Accident Reporting System (FARS), which is run by the NHTSA. The hotline could probably play an important role in identifying problems, especially because there is 
considerable economic incentive for litigators and people injured by fuel system malfunctions to alert NHTSA and provoke a formal investigation. Of the two computerized systems, NFIRS theoretically requires the most detailed reporting. Evaluation of the robustness of reporting in NFIRS would be most useful in predicting the likelihood that the system could be relied on as an early warning system for fire safety issues related to new fuels.

Another issue concerning fuel spills is that alcohol fuels will migrate to local drinking water supplies considerably faster than will gasoline constituents because of their solubility in water. This danger, which is particularly acute for methanol, will require a faster response system for monitoring wells and drinking water intakes after a spill to avoid damage to public health.

2. Are the magnitude and pace of penetration of new fuels into the marketplace likely to stress the current response system for hazardous material spills?

Short answer: We do not know for certain, but this situation is unlikely. The effectiveness of the current response system was last evaluated over 10 years ago; an updated evaluation is necessary.

Discussion: In the higher of our two market-penetration scenarios, PNGV $3 \mathrm{X}$ vehicles will account for only 5\% of total light-duty vehicle fuel use in 2020 , expanding to $26 \%$ in 2030 . On a volumetric basis, methanol would be the worst case (hydrogen is less dense, but it is unlikely to be widely transported), with $41 \%$ of total LDV fuel volume in 2030. In terms of total hazardous material shipments, the effect on rail shipments would be modest because gasoline is not widely shipped by rail. At $41 \%$ of LDV fuel volume, methanol would represent about $14 \%$ of truck shipments of hazardous materials in 2030, assuming no growth in total hazmat shipments. This is a moderate rate of introduction in terms of stress on transport and spill response infrastructure, but it is very much in keeping with historical rates of introducing significant new technologies.

One area of uncertainty is the lack of a recent assessment of the effectiveness of the hazardous material spill response infrastructure. It would be useful to conduct one.

\section{How will the widespread introduction of new fuels complicate the job of local fire departments in dealing with vehicle fires?}

Short answer: Additional training will be necessary, but equipment should not be a major problem. Gaseous fuels represent an added explosion danger.

Discussion: Local firefighting organizations represent the most obvious part of the safety infrastructure directly affected by the introduction of new fuels. The different fire characteristics of the new fuels - the explosive danger of hydrogen and DME in particular, but also the invisible flame of methanol and hydrogen and the lower 
emissivities of the alcohol fuels (which will allow firefighters to get closer to fires) - imply a substantial training requirement, which is an especially significant issue for small, rural fire stations. However, there appears to be no problem with equipment - new multipurpose foams are capable of knocking down a wide variety of fires, and the most likely result of a greater variety of fuels is that local fire companies will automatically use the more sophisticated foams in fighting all vehicle fires.

4. Will the need to maintain and repair large numbers of vehicles using new fuels create significant safety problems for the maintenance and repair infrastructure?

Short answer: The maintenance and repair infrastructure appears well equipped to adjust to handling new fuels, although the incentives to make the appropriate investments could be a problem during the earliest stages of a fuels shift. Hydrogenfueled vehicles will need special handling.

Discussion: Potential safety issues for the maintenance and repair infrastructure concern training mechanics to handle new fuels and installing additional safety equipment in facilities. Training does not appear to be a significant problem given the substantial and continuous influx of new technology into the vehicle market during the past decade, which has required essentially continual retraining of mechanics. However, the auto companies must ensure that appropriate training materials are available. Similarly, repair facilities have had to frequently upgrade their equipment, and changes to accommodate new fuels should not be out of line with other expenditures for new equipment. The most problematic period for the infrastructure will probably be the first few years after fuels introduction. When the number of vehicles using new fuels is small, and repairs are relatively infrequent, there may be a strong economic disincentive against spending on training and equipment.

Hydrogen fuel, with its propensity to leak and potential to explode, may represent the biggest challenge to the maintenance and repair infrastructure. Extremely careful attention to leak detection and suppression of potential ignition sources will be necessary for this fuel.

\section{Will home storage (garages) of vehicles using new fuels create unusual problems?}

Short answer: In most cases, home storage of new fuels should not present much of a problem. For hydrogen-fueled vehicles, however, hydrogen detectors will probably be required.

Discussion: Most new fuels do not represent any special fire danger in home garages, with the exception of hydrogen and possibly DME. With hydrogen, undetected leaks could be extremely serious, and low-cost detectors will have to be developed, installed, and maintained (note that battery replacement for home smoke detectors is an ongoing problem) where hydrogen-fueled vehicles are garaged. Concerns about 
other issues, especially toxic qualities (methanol), appear unwarranted, primarily because home garages already store a wide variety of dangerous materials, including pesticides, methanol (in windshield washer fluid), paints, and solvents.

\section{S.3 Safety Risks Associated with Alternative Fuels}

The focus of this study is not on measuring and comparing the safety risks of the fuels examined. However, we reviewed these risks in order to identify the related infrastructure concerns.

Fuels safety analysis is complicated and involves careful examination of numerous scenarios involving vehicle crashes in tunnels and in the open, spills onto land and water, and other safety incidents under a wide variety of conditions (e.g., poor to excellent ventilation [or still to breezy wind conditions], alternative ambient temperatures, and availability of ignition sources). Different analyses have arrived at widely varying conclusions about the relative safety of different fuels, with methanol and hydrogen safety being particularly controversial.

Gasoline appears to be an extremely dangerous fuel given its high flammability, heavierthan-air vapor (which can travel considerable distances to ignition sources), wide flammability limits, high heat emissivity (so that materials away from the fire can be ignited by it, and persons can be severely injured or killed even without coming into direct contact with flames), and production of toxic fumes when burned. Nevertheless, despite the ubiquity of this fuel in our society and the frequency of crashes, fire (not necessarily fuel-related) occurred in only 1,460 fatal crashes (2.6\% of all fatal crashes) and only 12,000 crashes $(0.1 \%$ of all vehicle crashes) in 1997 (NHTSA 1999) *f As noted above, there were fewer than 800 deaths in 1986 (and presumably fewer now) from gasoline-ignited vehicle fires.

There is little indication that alternative fuels will have a worse record, at least after the postulated "transition period" passes, and some are likely to do considerably better. Briefly:

- Diesel fuels (RFD, F-T diesel, biodiesel) pose a much lower fire danger than gasoline and are actually quite difficult to ignite.

- $D M E$ is stored in stronger vehicle tanks than gasoline, disperses more quickly after a spill, and burns with less thermal radiation and less smoke than gasoline. Also, it presents no danger of land contamination. It is more explosive than gasoline, so an indoor spill is particularly dangerous.

- Ethanol is less likely to burn or explode than gasoline, and ethanol fires are less dangerous. Because ethanol fumes can explode in storage, storage tanks must be carefully designed. This fuel's most significant danger is probably its potential for misuse, since ethanol is drinking alcohol; even as a denatured fuel, it will probably still pose a risk. If spilled into marine waterways, ethanol is toxic to marine life in high concentrations but quickly dilutes in open water, with no residue.

\footnotetext{
* NHTSA, 1999, Fatal Accident Reporting System Data on NHTSA web site (www.nhtsa.dot.gov).
} 
- Methanol is also less flammable and explosive than gasoline and causes less damage when ignited. Like ethanol, storage represents a potential risk; risk reduction requirements are therefore similar to those for ethanol. Because this fuel burns with a near-invisible flame, it poses some additional risk for firefighters and others near a fire. Toxicity to humans and the environment is the major safety concern associated with methanol. It could be misused as an intoxicant, with disastrous effects, including death. If spilled into marine waterways, methanol's effect on marine life is similar to that of ethanol: toxic in high concentrations but quickly diluted in open water, with no residue. A major spill issue is contamination of drinking water supplies; however, methanol biodegrades fairly rapidly in open waters or even in shallow aquifers with high oxygen content.

- Compressed hydrogen is harder to characterize as to relative safety than the other fuels. It poses no environmental danger from spills; can be stored in an extremely strong tank onboard the vehicle; disperses in a spill much more quickly than gasoline; and, in most cases, is much less dangerous than gasoline if ignited. However, a leak or spill in an enclosed area is quite likely to lead to an explosion, and fuel tank explosion is a plausible risk (although rigid guidelines for tank design could minimize this risk). Hydrogen embrittles some metals, so care must be taken in selecting materials for hydrogen storage and use. A hydrogen fire is invisible, and hydrogen is odorless, adding to its risk. Moreover, because hydrogen has very small molecules, it is very prone to leak. Because of hydrogen's characteristics, hydrogen detectors need to be a mandatory fixture in home garages or any enclosed area where hydrogen-fueled vehicles are stored. 


\section{Section 1 \\ Introduction and Background}

\subsection{Introduction}

In this report, we discuss safety-related infrastructure requirements and concerns that may arise from the use of alternative fuels in highly fuel-efficient vehicles under the Partnership for a New Generation of Vehicles (PNGV) program. In the context of this report, safety-related infrastructure requirements and concerns encompass a range of needs, including (1) developing new codes and standards related to alternative fuels and associated infrastructure, (2) training mechanics so that they can address new safety concerns in the repair of alternative-fuel vehicles, (3) developing new kinds of firefighting equipment, and (4) training firefighters to deal with fuels that have ignition and burning characteristics different from those of gasoline. This report is meant to highlight and discuss key issues about infrastructure needs to maintain fuel safety; it is not, in any sense, meant to be a definitive analysis of vehicle and fuel safety.

The fuels of concern include different kinds of diesel fuel (reformulated diesel, FischerTropsch diesel, and biodiesel), dimethyl ether, ethanol, methanol, and compressed hydrogen. Vehicle technologies include hybrid drivetrains powered by direct-injected, spark-ignited or compression-ignited engines and by fuel cells. In the context of this report, the term "safety" encompasses fire and explosion hazards associated with fuel leaks, vehicle collisions, and large fuel spills or spills of materials used in producing the fuels; human exposure to toxic materials associated with spills or other means of contact with fuels and production materials; and contamination of water or land from spills. 1n other words, we are concerned about safety across the fuel cycle, not just onboard the vehicle. However, this report focuses primarily on the "downstream" part of the fuel cycle, especially on fuel storage, transport of fuel to local service stations, in-station refueling, vehicle operation, and vehicle maintenance and repair.

\subsection{Background}

The PNGV is a joint research and development effort by the U.S. government and the U.S. Council for Automotive Research (USCAR), which includes DaimlerChrysler, Ford, and General Motors. The PNGV's primary goal is to develop vehicles that can achieve up to three times the fuel economy of today's vehicles ("3X vehicles"), which equals about 80 miles per gallon for six-passenger family-sized cars, without sacrificing the performance, size, utility, or cost of ownership and operation and while meeting all safety and emissions requirements expected to be in place when they are introduced. The PNGV began in September 1993, and the three participating automakers have recently displayed prototype vehicles incorporating such

1 In considering water or land contamination as safety issues, only spills resulting from significant releases during an accident or other incident are considered. Contamination caused by spills from slow leaks (e.g., from leaking underground storage tanks) is considered an environmental (not a safety) issue and is beyond the scope of this analysis. 
technologies as hybrid-electric drive, direct-injection engines, fuel cells, and lightweight materials.

In its 1994 report, the National Research Council's (NRC's) Peer Review Committee for PNGV asked for an in-depth assessment of the changes that could occur in infrastructure, including the need for new safety strategies, associated with each technology being explored in the PNGV program (NRC 1994). The option of shifting away from conventional gasoline and diesel to alternative fuels was recognized as potentially desirable or necessary for $3 \mathrm{X}$ vehicles — and the need for developing the infrastructure for producing, distributing, and using new fuels was seen as a potential challenge for the PNGV.

In response to the NRC's Peer Review Committee's recommendation, Argonne National Laboratory (ANL) conducted a series of analyses of fuel-related infrastructure issues for the Office of Advanced Automotive Technologies (OAAT) in the U.S. Department of Energy (DOE) to quantify major impacts resulting from the commercialization of $3 \mathrm{X}$ vehicles. ANL's latest effort was an analysis of (1) the cost to build the fuel production and distribution infrastructure needed for each of the fuels under consideration for $3 \mathrm{X}$ vehicles and (2) the likely fuel-cycle energy and air pollutant impacts of using each of those candidate fuels. For that effort, ANL characterized fuel production technologies and distribution infrastructures and estimated $3 \mathrm{X}$ vehicle stocks and fuel use for the period 2007 through 2030 under two scenarios of 3X market penetration.

In this study, however, we focus on identifying and clarifying key safety-related infrastructure issues rather than conducting a quantitative analysis. For consistency, we target the same 2007-2030 time frame and adopt the same market-penetration scenarios used in the prior work. The scenarios are:

- Baseline. The DOE Energy Information Administration's 1997 forecast of energy use to 2015 (DOE 1996), extrapolated to 2030. This forecast does not include the introduction of any $3 \mathrm{X}$ vehicles.

- Low market share. The $3 X$ vehicles enter the market in 2013 and capture a $30 \%$ share of the new LDV market by 2030.

- High market share. The $3 X$ vehicles enter the market in 2007 and capture a $60 \%$ share of the new LDV market by 2030.

As in the prior analysis, we examine each fuel in turn as if it captures the entire market for $3 \mathrm{X}$ vehicles. In most instances, this represents a "worst case," which is useful to examine. Also, historical precedent suggests that, for competing technologies of this nature, one technology will become dominant following a period of vigorous competition. However, we do not adhere strictly to this convention, because we can imagine situations where multiple new fuels could be more of an infrastructure challenge than only one (e.g., the additional challenge to local fire stations of dealing with several new fuels). In other words, we attempt to identify important safety concerns that may arise from other plausible scenarios. 
To identify important infrastructure requirements or concerns, we compare the safety concerns of new fuels with concerns associated with the baseline scenario and fuel. We assume the baseline fuel to be federal Phase 2 reformulated gasoline (RFG). Phase 2 RFG is scheduled to replace federal Phase 1 RFG in 2000. Phase 1 RFG is mandated in nine of the most severe ozone nonattainment areas of the United States, with a more stringent formulation mandated by the state of California. Additional states have opted into the RFG program despite their attainment status, and a significant proportion of the U.S. light-duty fleet will likely be using federal Phase 2 RFG at the time $3 \mathrm{X}$ vehicles enter the fleet. For this study, we assume that Phase 2 RFG will be used for all conventional vehicles; spark-ignition, direct-injection (SIDI) hybrids; and (some) fuel cell vehicles.

The alternative fuels we examine include the following:

1. Reformulated diesel (RFD), which is used in compression-ignition, direct-injection (CIDI) engines. Our initial assumption was that this fuel would have $100 \mathrm{ppm}$ sulfur (by weight) and low aromatic content. Recent developments in emissions requirements for diesel-fueled vehicles imply that sulfur requirements may well be more stringent than this (about $30 \mathrm{ppm}$ ), with aromatic content not much lower than that of today's fuels.

2. Dimethyl ether (DME), which is used neat in CIDI engines. DME is a gas that can be stored as a liquid at moderate pressures. It is synthesized from natural gas and is sulfurfree.

3. Fischer-Tropsch (F-T) diesel, which is used in CIDI engines, is produced by synthesis reaction of natural gas, has zero sulfur content, and low aromatic content. A blend of $50 \% \mathrm{~F}-\mathrm{T}$ diesel and 50\% RFD is assumed.

4. Biodiesel, which is used in CIDI engines, is produced by processing agricultural products, such as soybean oils (in this case, from the transesterification of soy oil to form methyl ester, or soyate). A blend of 20\% biodiesel and 80\% RFD is assumed.

5. Methanol, which is used in SIDI engines and fuel cells, is produced via synthesis gas reaction from natural gas. We assume it will be used as M100, that is, $100 \%$ methanol.

6. Ethanol, which is used in SIDI engines and fuel cells, is assumed initially to come from corn, with production gradually shifting to cellulosic feedstocks. We assume it will be used as E100.

7. Compressed hydrogen, which is used in fuel cells, is assumed to be produced prior to 2020 from natural gas; thereafter, incremental supplies are assumed to come from solar sources through water electrolysis. 
$\Delta$ 


\section{Section 2 \\ Measuring Fuel Safety}

To identify the infrastructure implications associated with the safety of alternative fuels used by PNGV vehicles, the potential safety concerns of these fuels need to be identified first. Measuring and comparing the safety of alternative fuels involves the following tasks:

- Identifying and examining well-defined physical/chemical characteristics of fuels that have safety implications (e.g., upper and lower flammability limits, which are typically expressed as percentages of fuel vapors or gases in air that define the range of concentrations that can be ignited);

- Identifying unique fuel qualities that may also have safety implications (e.g., hydrogen embrittlement of metals, or usefulness of methanol as a degreasing agent, which might encourage its storage in garages);

- Identifying institutional and infrastructure conditions that might increase the likelihood of incidents affecting public safety or involving serious environmental damage, or identifying conditions that might prevent an adequate response to such incidents (e.g., the presence or absence of storage safety standards and the availability and level of training of emergency response teams);

- Identifying situations in which the introduction of a fuel needed to meet PNGV requirements could lead to changes in the general fuel pool (e.g., low- or zero-sulfur diesel fuel being used by older trucks), with unintended consequences; and

- Evaluating these factors in the context of scenarios of potential injury-causing incidents (e.g., fuel leakage in a residential garage and a collision affecting fuel tank integrity).

The complexity of this type of analysis should not be underestimated. Fuel safety depends on the complex interaction of dozens of fuel properties with (1) the nature of the fuel's production, storage, distribution, and use onboard the vehicle; (2) established rules and regulations; and (3) human nature. Human nature is important because risk perception may be as important as risk reality; for example, a fuel with extreme safety risks may be safer than one with more subtle risks because users may handle the former with far more care. 


\subsection{Physical/Chemical Characteristics}

Fuels have a variety of physical and chemical characteristics that affect their safety. These can be separated into the following:

1. Properties that predict the likelihood that fuels will be released into the environment,

2. Properties that predict whether direct contact with the fuels or their degradation products are likely to harm the environment or public health, and

3. Properties that predict the likelihood that fuels will ignite or explode and the danger of a fire or explosion to people and property.

The following subsections briefly describe some of the more important safety-related fuel properties.

\subsubsection{Properties Affecting the Likelihood of Spills or Releases}

Fuel energy density. This property determines the physical volume of fuel transported to satisfy a given energy demand. Fuel energy density should provide a good comparative measure of each fuel's exposure to events that might cause spills or releases during fuel distribution.

Nature of distribution and storage infrastructure. Generally, distribution by pipeline should yield a lesser risk of spills and releases than tanker-truck-based distribution. Required storage in tanks specifically designed for the fuel should minimize the likelihood of leaks.

Corrosivity/reactivity. This property determines fuel effects on containment materials and material incompatibilities. Mild corrosivity or reactivity may actually present more of a problem than extreme corrosivity/reactivity because fuel distributors, vehicle designers, and fuel users are more likely to take greater care in equipment design and fuel handling with highly corrosive or reactive fuels.

Inherent safety of storage tanks. The need to use high pressures in gaseous fuel storage systems demands extremely strong storage tanks that are less likely to fail in a collision than a conventional tank for liquid fuels; however, such tanks may present increased risk if they do fail.

\subsubsection{Properties Affecting the Threat to Human Health and Environment after a Release}

Toxicity. This property encompasses a variety of measures that define either the harmful effects on people, plants, or animals of a given exposure to the fuel, or the level of exposure that causes a defined injury or reaction, including death.

Miscibility with water. Miscibility measures the fuel's ease of mixing with water and therefore the likelihood that it will contaminate underground aquifers. A good example is the addition of the oxygenate MTBE, which is water soluble, to gasoline. Extensive leakage 
from underground gasoline storage tanks has resulted in widespread MTBE contamination of drinking water supplies.

Biodegradability. This property affects the longevity of toxic materials in the environment.

Taste and odor. These characteristics determine the degree to which drinking water acceptability can be degraded, but they also determine the ease of detection of contamination without testing.

\subsubsection{Properties Affecting Fire and Explosion Danger after a Fuel Release}

Measuring the likelihood of fire and explosion after a fuel release is complex and involves a multilayer analysis that accounts for the amount of explosive vapor that forms and where it is likely to travel, the ease with which such vapor will ignite or explode, and the damage that is likely if ignition or explosion occurs. In other words, a chain of events must occur for property or persons to be harmed in a fire or explosion from a fuel release, and different properties identify the probabilities associated with each link of the chain.

Link 1: How much vapor is there, and how fast is it likely to disperse?

Vapor pressure - determines the rate at which vapor is produced from exposed fuel.

Vapor density - compared with air (=1.0), determines whether the vapor will tend to stay near the ground and collect in depressions (at high densities and under still air conditions)

or, at the other extreme (low density), rise and, if outdoors, quickly disperse (if indoors and without ventilation, low-density vapor might collect at the ceiling).

Diffusion coefficient and velocity, buoyant velocity - determines the extent and speed of dispersal and mixing of vapors. Rapid dispersal is a positive feature in an outdoor spill, but it is somewhat of a negative one indoors because it can quickly lead to a combustible mixture of air and fuel.

\section{Link 2: How easily ignited is the fuel or vapor?}

Lower and upper flammability limits - minimum and maximum percentage of vapor mixed with air that allows ignition. The lower flammability limit (LFL) is most important because it defines the point at which the vapor pressure building up after an accident becomes ignitable; a low LFL means it does not take much vapor to form an ignitable mixture. However, a low upper flammability limit (UFL) is an advantage because releases in an enclosed space can build up vapor concentrations rapidly; spills of fuels with low UFLs will quickly yield a mixture of vapor and air that has too much vapor (is too "rich") to ignite. 
Ignition temperature and energy — the temperature and energy of a spark or flame needed to ignite a fuel/air mixture, which depends on the actual mixture. In reality, many ignition sources will produce enough energy to ignite virtually any fuel.

Flash point - minimum temperature at which the fuel gives off enough vapor to form an ignitable mixture near the surface of the liquid.

\section{Link 3: Once ignited, how dangerous is the fire or explosion?}

Flame visibility - extent to which flame is visible in bright sunlight. Some fuels (e.g., methanol and hydrogen) burn with a flame that is essentially invisible in sunlight, a characteristic that greatly increases the danger that an unwary person could walk into the fire.

Burning velocity - speed of the advancing flame with respect to the unburned gas mixture ahead of it (which may be moving because of the pressure of approaching combustion gas); high burning velocities indicate high explosive potential.

Flame emissivity - affects the heat transferred by radiation to objects near the flame, and thus the potential for secondary ignitions and burns from radiation.

Adiabatic flame temperature - temperature at which the fuel-air mixture burns.

Existence of firefighting problems (e.g., fires not controllable with common firefighting materials) - affects the risk to firefighters and/or requirements for new firefighting equipment and training.

\subsection{Other Factors with Safety Implications}

Table 1 summarizes key safety-related characteristics of alternative fuels. In addition to these characteristics, other factors may affect the overall danger of alternative fuels by affecting the likelihood that they will be misused. For example, the existence of household uses for the fuel (e.g., as a household fuel or degreasing agent) will affect whether the fuel will likely be stored in residential garages and other areas that might be accessible to children. Any potential that the fuel may be misused as a beverage, which is obviously a problem with ethanol and perhaps also with methanol (through misunderstanding of its true chemical nature), can affect the safety of new fuels.

Finally, the familiarity of people with the fuel and its hazards is important. It may be inevitable that there will be a period after the introduction of a new fuel during which its risks will be elevated because of its newness. 
Table 1 Important Safety-Related Characteristics of Alternative Fuels

\begin{tabular}{|c|c|c|c|c|c|c|c|c|}
\hline Parameter & RFG & RFD & $\begin{array}{c}\text { F-T } \\
\text { Diesel }\end{array}$ & Biodiesel & Methanol & Ethanol & DME & Hydrogen \\
\hline \multicolumn{9}{|c|}{ Physico-Chemical Properties } \\
\hline $\begin{array}{l}\text { Flammability } \\
\text { Limits } \\
\text { (vol\% in air) }\end{array}$ & $1.0-7.6$ & $0.6-5.6$ & $\begin{array}{c}0.5- \\
\text { unknown }\end{array}$ & - & $6.7-36$ & $3.3-19$ & $3.4-27$ & $4.0-75$ \\
\hline $\begin{array}{l}\text { Detonability } \\
\text { Limits } \\
\text { (vol\% in air) }\end{array}$ & $1.1-3.3$ & - & $3.4-19$ & - & - & - & $3.4-19$ & $13-59$ \\
\hline $\begin{array}{l}\text { Vapor Gas } \\
\text { Pressure } \\
\left.\text { (psi@100 }{ }^{\circ}\right)\end{array}$ & 7 & Negligible & - & - & 4.6 & 2.5 & 120 & - \\
\hline $\begin{array}{l}\text { Minimum } \\
\text { Ignition Energy } \\
\text { in Air }(\mathrm{mJ})\end{array}$ & 0.24 & $0.3^{\mathrm{a}}$ & - & - & 0.14 & - & 0.45 & 0.02 \\
\hline $\begin{array}{l}\text { Autoignition } \\
\text { Temperature }\left({ }^{\circ} \mathrm{F}\right)\end{array}$ & $442-880$ & 500 & 410 & - & $464 / 725$ & $423 / 685$ & $450 / 662$ & $750 / 930$ \\
\hline Flashpoint & -45 & $125^{\mathrm{b}}$ & 200 & - & 52 & 54 & -42 & Gas \\
\hline $\begin{array}{l}\text { Density of } \\
\text { Gas/Vapor } \\
\text { (Relative to Air } \\
=1.0 \text { ) }\end{array}$ & $3.4-4.0$ & $4.0-6.0$ & $4.0-6.0$ & $4-10.0$ & 1.1 & 1.6 & 1.6 & 0.07 \\
\hline $\begin{array}{l}\text { Relative Heat } \\
\text { Release Rate, } \\
\text { Pool Fires }\end{array}$ & 1.5 & 1 & - & $4-10.0$ & $\sim 0.25$ & $\sim 0.25$ & NA & NA \\
\hline Emergency Respo & Ise Guida & nce & & & & & & \\
\hline Immediate Spill & $25-50$ & $25-50$ & $25-50$ & $25-50$ & ח200 100 & $25-50$ & $50-100$ & $50-100$ \\
\hline $\begin{array}{l}\text { Large Spill } \\
\text { Evacuation } \\
\text { Distance }(m)\end{array}$ & 300 & 300 & 300 & 300 & 100-200 & $25-50$ & $50-100$ & $50-100$ \\
\hline $\begin{array}{l}\text { Tanker Fire } \\
\text { Isolation } \\
\text { Distance }(\mathrm{m})\end{array}$ & 800 & 800 & 800 & 800 & 800 & 800 & 1,600 & 1,600 \\
\hline
\end{tabular}

${ }^{\text {a }}$ Estimated

${ }^{\mathrm{b}}$ Minimum

Sources: Murphy (1997); Machiele (1990a); Bain et al. (1998); OMS (1990); Pitstick (1993); Thomas (1997); Argonne National Laboratory/University of Chicago Chemical Management System, ESH-Industrial Hygiene Material Safety Data Sheets. 
$\Delta$ 


\section{Section 3 \\ Overview of the Safety of Alternative Fuels}

The following discussion presents a broad overview of the safety of the seven alternative fuels discussed in Section 1, in comparison with reformulated gasoline. As noted, the focus is on the downstream portions of the fuel cycle, and the evaluation is broad-brush. Rather than provide an exhaustive analysis of these issue, which is beyond the scope of this report, we provide an overview of the nature of potential infrastructure issues associated with fuel safety.

\subsection{Reformulated Gasoline}

Reformulated gasoline represents the baseline against which the safety of alternative fuels will be measured. Although reformulated gasoline is somewhat different in composition from the gasoline that has fueled most of the U.S. automobile and light-truck fleet for many decades, it is similar enough that the fire safety history of the fleet would not have been much affected by shifting between them. It seems reasonable, then, to use the recent fire safety record of the fleet as a "worst-case" measure of the baseline. New PNGV vehicles, if fueled by gasoline, would likely be substantially safer than this history would indicate, because modern crash design protects the gas tank much better than in the past, and the design and materials of the PNGV vehicle's fuel delivery system - representing the cutting edge of post-2000 design and technology — would likely be substantially better as well.

Vehicle fires and explosions appear to play a relatively small role in vehicle injuries and fatalities. For example, in 1997, fire occurred in 1,460 fatal crashes, or $2.6 \%$ of all fatal crashes (NHTSA 1999). The data, which are from the Fatal Accident Reporting System, do not indicate whether fire was the cause of death, and presumably in many of the crashes, it was not. Data also show that fire occurred in $0.1 \%$ (12,000 out of about 12 million) of all vehicle crashes. In other words, although gasoline fuel tanks (the great majority of crashes involve gasoline-fueled vehicles) are not especially strong and gasoline is a highly flammable fuel, fire is a relatively rare occurrence in vehicle crashes.

Crashes are not the only cause of vehicle fires, and the majority of such fires stem from other causes (e.g., leaks in fuel lines and catalytic converters igniting combustible material). The U.S. Environmental Protection Agency (EPA) reported 500,000 vehicle fires and 1,400 vehicle fire fatalities for the United States in 1986; in 180,000 of the fires, gasoline was the first material to ignite, resulting in 760 deaths, 4,100 serious injuries, and \$215 million in property damage (OMS 1998).

This history likely represents the worst-case fire scenario not only for gasoline but also for the other alternative fuels, assuming that adequate safety measures with such fuels are implemented. Gasoline appears to be at least as dangerous a fire hazard as the other fuels, although its ignition and combustion characteristics are quite different from those of some of the fuels. Gasoline's physical characteristics make outdoor spills quite dangerous. It readily forms a vapor, the flammability limits of which range from $1 \%$ to about $8 \%$ in air; these limits are wide 
enough that an open flame is almost always extremely dangerous in the presence of a spill. Gasoline's vapor is two to five times as dense as air, 2 so the vapor will tend to travel along the ground rather than dispersing readily and will ignite when it reaches a flame or spark. When gasoline does ignite, it burns very quickly and releases heat at a far higher rate (six times faster) than methanol or ethanol. The emissivity of the flame is high enough for many combustible materials to ignite well before the flame actually reaches them. Thus, the flame from a gasoline fire can severely injure or kill people without actually touching them. Finally, a gasoline fire will produce large quantities of black smoke and toxic gases that are both highly dangerous to exposed individuals and capable of causing substantial property damage.

Gasoline's high volatility is a safety advantage in storage, because the vapor concentration inside a gasoline storage tank typically is well above the upper flammability limit (i.e., the vapor is too "rich" to burn). At low temperatures $\left(-20^{\circ} \mathrm{F}\right.$ to $\left.-40^{\circ} \mathrm{F}\right)$, however, volatility is low enough that the vapor in gasoline fuel tanks is likely to be within the flammable limits.

Gasoline is also dangerous to humans through direct exposure. Ingestion is extremely dangerous (though considerably less so than methanol) because the gagging and coughing reflex may allow gasoline to get into the lungs, causing a pneumonia-like condition. Death can occur in some individuals from ingesting as little as 0.025 pint if some of the fuel is aspirated into the lungs, although it usually takes at least 10 times as much (Machiele 1990b). Even minor contact can cause skin irritation and cracking. Inhaling high concentrations of gasoline vapor — which could occur from a spill in an enclosed area, for example - can cause narcosis, coma, or death from severe central nervous system depression, which causes respiratory failure (Machiele 1990b).

Emergency response guidelines for gasoline stipulate initial downwind evacuation after a large spill of at least $1,000 \mathrm{ft}$ downwind and $0.5 \mathrm{mi}$ in all directions from a burning tank or tanker (DOT, Transport Canada, and Secretariat of Transport and Communications, Mexico, 1996).

\subsection{Diesel Fuel — RFD, Biodiesel, F-T Diesel}

Diesel fuel is generally considered to be the safest petroleum fuel, as well as the safest highway vehicle fuel among the full range of alternatives to gasoline, with the possible exception of electricity. This assertion is true for virtually every individual threat scenario. The reasons are as follows:

1. Low fire danger. Despite a relatively low $0.6 \%$ lower flammability limit, diesel's volatility and vapor pressure at ambient temperature are so low that it does not easily ignite after a spill. Diesel is also generally not considered to pose a significant danger in storage because the vapor is too lean to ignite with a spark (in contrast, as noted above, gasoline is so volatile that stored gasoline will not ignite because the vapor is too rich; that is, the vapor is above the UFL). An exception may be on hot, sunny days when temperatures inside exposed storage tanks can get well above $100^{\circ} \mathrm{F}$ and diesel volatility increases. There have been rare cases of aboveground

2 Depending on gasoline composition, which is quite variable. 
diesel storage tanks exploding; however, an unknown portion of these incidents may have been caused by contamination of the stored fuel with gasoline. There have also been incidents of explosions in fuel tanks of heavy-duty diesel trucks, apparently when the fuel tanks were almost empty (Bisio 1999; Naegeli and Childress 1998).

2. Low explosion danger. Although fuel explosions are rare, they are so damaging that they have relatively high weight in risk assessments. Diesel's explosion risk is very low in most scenarios, but emergency response guidelines demand evacuation distances identical to those for gasoline - within 1,000 ft downwind of a spill and $0.5 \mathrm{mi}$ in all directions from a tank or tanker fire.

On the negative side, diesel fuel will ignite if heated sufficiently (diesel fuel is more susceptible than gasoline to ignite on contact with hot surfaces, such as exhaust manifolds), and diesel fires have higher thermal radiation than fires fed by alternative fuels and generate a great deal of smoke, both of which create a high risk of injury. Thus, a diesel-fueled vehicle involved in a fire is quite susceptible to having its fuel ignite if it is released.

Physical contact with diesel fuel through skin contact, inhalation of vapors, and ingestion is dangerous to humans. The fatal dose from ingestion with aspiration may be about one-half that of gasoline (Machiele 1990b), and smaller doses are extremely damaging. Acute inhalation exposure is also extremely dangerous, although diesel's low volatility makes such exposure quite rare (Machiele 1990b). Prolonged skin contact can lead to absorption through the skin and narcosis; however, this is more an occupational hazard than a pure safety problem as defined here.

Biodiesel fuel (B20) contains $80 \%$ diesel fuel and thus its safety characteristics are quite similar to those of diesel. Because its flash point is significantly higher than pure diesel's (about $250^{\circ} \mathrm{F}$ vs. $100-190^{\circ} \mathrm{F}$ ), it is even less likely to ignite after a spill (FTA 1995). On the other hand, biodiesel is incompatible with some nonmetal materials, so it cannot be marketed without assuring that fuel system materials are not degraded.

California's implementation of lower sulfur diesel fuel requirements resulted in a number of problems, including increased fuel leaks (Volpe National Transportation Systems Center 1998). This experience, coupled with the materials incompatibility concerns about biodiesel, implies that future reformulation of diesel fuels (and gasoline) for PNGV requirements will need to take into account the likelihood that these fuels will be used by the general population of vehicles and may replace conventional diesel in the distribution network. There will be potential materials compatibility issues in both arenas, with safety implications if leaks and spills increase.

\subsection{Dimethyl Ether (DME)}

Dimethyl ether is a gaseous fuel that is stored as a liquid under pressure. It is best suited for compression-ignition (diesel) engines. Although significant energy is required to manufacture it from natural gas, in contrast to the low energy cost of refining diesel fuel and gasoline (thus diluting the potential greenhouse benefits of using DME), DME is valued because its use greatly diminishes particulate and $\mathrm{NO}_{\mathrm{x}}$ emissions from diesel engines. 
DME is similar to propane and generally shares its safety characteristics. On the positive side, in comparison with gasoline, DME is likely to have the following qualities:

1. Low spill probability in collisions. Pressurized storage tanks for propane, and presumably for DME, are substantially stronger than conventional gasoline or diesel storage tanks, thus they are less vulnerable in a collision if equally well-protected (van der Weide 1980).

2. Faster dispersion after a spill. Although DME is heavier than air and thus has a tendency to flow along the ground and settle in low-lying areas, its relative density is much lower than that of gasoline vapor, 1.5 compared to 3.4-4.0 (and gasoline persists for long periods whereas DME does not). Thus, DME disperses much more quickly than gasoline, presenting a risk for only a comparatively short time after a spill.

3. Lower danger after ignition. DME burns with a visible flame, burns with less thermal radiation than either gasoline or diesel, and produces less smoke, which results in lower danger of harm than from gasoline.

On the negative side, DME is likely to have the following drawbacks:

1. Greater explosion hazard. DME has wide detonability limits, $3.4-19.0 \%$ in air, presenting a substantial explosion hazard in such situations as a spill in a residential garage. For large spills or tanker fires, this explosion danger dictates significantly higher evacuation/isolation distances than gasoline $-0.5 \mathrm{mi}$ (versus $1,000 \mathrm{ft}$ for gasoline) for a large spill, $1 \mathrm{mi}$ (versus $0.5 \mathrm{mi}$ ) for a tanker fire (DOT, Transport Canada, and Secretariat of Transport and Communications, Mexico, 1996). DME is probably more of an explosion hazard than propane (J.E. Sinor Consultants, Inc., 1997).

2. Similar to higher flammability. In fuel-line leaks and some collision scenarios, DME is more likely to ignite than gasoline. In other risk scenarios, it has flammability and explosion hazards similar to those of gasoline (Krupka, Peaslee, and Laquer undated).

3. Persistence in low-lying areas, and therefore remaining a fire and explosion hazard. DME is lighter than gasoline vapor, so an equal amount will disperse more quickly. However, it is still heavier than air, so in still-air conditions a DME gas cloud, like a gasoline vapor cloud, can flow along the ground and ignite if it reaches an ignition source. Also, a DME release becomes a gas essentially instantly, unlike gasoline, which vaporizes slowly. Thus, a DME release generates a much larger (flammable) gas cloud than release of an equal quantity of gasoline. 


\subsection{Ethanol (Ethyl Alcohol)}

Currently, ethanol is widely used as a $10 \%$ component of "gasohol" and as an oxygenate in reformulated gasolines. At present, most ethanol used as a fuel component is manufactured from corn. The DOE has been sponsoring research on ethanol production from cellulosic materials, with the resulting fuel to be used as either a blending component or a "neat" fuel (that is, as $100 \%$ ethanol). Neat ethanol, or E100, can be used in a modified spark-ignited engine, or it can be reformed onboard a vehicle and used as a hydrogen carrier for a fuel cell.

Ethanol should be considerably less susceptible than gasoline to fire and explosion. It combines a lower flash point, low volatility, and relatively high LFL of 3.3\% (compared to gasoline's $1.4 \%$ ), and so is less likely to ignite than gasoline. Once ignited, ethanol burns with a visible flame (although it may be difficult to see in bright sunlight) and a heat release rate only one-fifth that of gasoline; ethanol's low heat release rate is due to its low heat of combustion and high heat of vaporization (OMS 1990). Nevertheless, emergency response guidelines for ethanol are essentially identical to those for gasoline (and diesel) - 1,000-ft evacuation downwind of a spill and 0.5-mi evacuation from a tank or tanker fire (DOT, Transport Canada, and Secretariat of Transport and Communications, Mexico, 1996).

Ethanol's main disadvantages from the standpoint of its relative fire and explosion risk are its combustibility in storage and some materials incompatibility problems, especially when the ethanol has absorbed some water. Unlike gasoline, which has vapor that is too rich, ethanol's vapor tends to be in the combustible range inside storage tanks. Technical solutions to the vapor flammability problem include nitrogen "blankets" inside storage tanks, bladder tops that prevent a flammable air space from forming inside the tank, and flame arrestors. Like gasoline vapor, ethanol vapor is heavier than air, and thus is similarly slow to disperse in calm air conditions — adding to its fire risk.

Ethanol represents only a moderate spill danger because it is water soluble and biodegradable, becoming diluted to nontoxic concentrations relatively quickly in most spill scenarios. However, in the immediate vicinity of a large spill or in confined waters, it destroys aquatic life (with relatively rapid recovery, however, since there is no residue) and may contaminate nearby drinking water intakes.

Unlike gasoline, ethanol is a poor degreaser. It is, however, widely used as a solvent, so it may be found in some home garages, even without its increased use as a motor fuel. With or without its storage in garages, widespread ethanol use represents a potential danger from misuse because it is drinking alcohol. Presumably, it will be mixed with a bad-tasting denaturant that will discourage such misuse, and antisiphoning mechanisms could be used in vehicle tanks, but it probably is naive to believe that attempts to use it for drinking will not be made. Additionally, ingestion of ethanol, although not as dangerous as gasoline, diesel fuel, or methanol, is still somewhat toxic and particularly dangerous to children.

Ethanol presents a moderate danger from other types of exposure (i.e., inhalation and skin contact). Although momentary inhalation of ethanol vapors is not dangerous, prolonged inhalation of high concentrations - an unlikely although not impossible part of an accident 
scenario - can cause respiratory failure (Pitstick 1993). However, ethanol vapor is substantially less toxic than methanol vapor (Murphy et al. 1995), which, in turn, probably presents a lower toxicity danger than gasoline vapor because of gasoline's high volatility. Skin contact is irritating and can cause defatting of the skin. Prolonged exposure should therefore be avoided.

\subsection{Methanol}

Methanol is considered to have significantly lower fire risk than gasoline because of its superior physical characteristics:

1. Low flammability in open areas. Methanol's low volatility (4.6 psi Reid vapor pressure vs. twice that for RFG) and relatively high LFL (about $6 \%$ vs. 1.4\%) means that achieving a flammable air/fuel-vapor mixture in open areas will not be easy (Machiele 1990a). This tendency toward reduced fire risk is bolstered by methanol's vapor density of 1.1 (compared with gasoline's 3.4-4.0); in other words, methanol vapor tends to disperse, whereas gasoline vapor tends to flow along the ground or accumulate in low areas, increasing the likelihood that it will reach an ignition source. On a still day, however, a slightly heavier-than-air methanol cloud could still reach flammability, and industrial guides do rate methanol's flammability as "extreme" (Argonne National Laboratory 1995).

2. If ignited, much lower heat release rate than gasoline. Methanol's low heat of combustion and high heat of vaporization mean that it burns only one-fourth as fast as gasoline (OMS 1998) and releases only one-fifth (OMS 1989) to one-eighth (OMS 1998) as much heat as gasoline.

Despite its apparently lower fire danger, methanol has emergency response evacuation guidelines similar to those of gasoline and diesel, particularly its 0.5 -mi evacuation requirement for tank and tanker fires (DOT, Transport Canada, and Secretariat of Transport and Communications, Mexico, 1996).

Methanol is similar to ethanol in that it creates a flammable fuel/air mixture in storage containers because of its low volatility coupled with wide flammability limits - 6.7-13\% at $70^{\circ} \mathrm{F}$. Unlike gasoline, methanol's fuel-vapor/air mixture does not get too rich to burn at normal ambient temperatures. In terms of fuel tank safety, methanol is similar to ethanol in that it requires the use of floating tops or bladders to minimize the air space and flame arrestors to prevent ignition. Methanol also burns with a near-invisible flame, creating the danger that firefighters or others might inadvertently move into a fire.

Methanol is toxic to plants and animals in high concentrations; thus, a large methanol spill poses risks to the environment and to drinking water supplies. However, methanol spills generally will be less damaging than spills of gasoline and other petroleum fuels. Methanol is less toxic to marine life than petroleum fuels (Machiele 1990b). Methanol is highly soluble in water, biodegradable, and subject to complete evaporation. Spills in confined waters are toxic, but most spills in water quickly dilute and disperse to nontoxic concentrations, with no longlasting residue, unlike petroleum spills (OMS 1989). One disadvantage of methanol's solubility 
is the risk of relatively rapid contamination of drinking water supplies from water spills near an intake or from groundwater contamination from a spill on land. Especially with a water spill, the type of containment often possible for a petroleum spill is not possible for a methanol spill. On the other hand, the greater likelihood that methanol will reach drinking water intakes or aquifers should be balanced somewhat by its greater biodegradability. Methanol rapidly biodegrades in open waters and even in shallow aquifers with high oxygen content (OTA 1989).

Methanol has been widely viewed as a dangerous fuel because of its acute toxicity when ingested. When swallowed, methanol is more toxic than gasoline and kills at lower concentrations - one ounce of methanol can be fatal to an adult, whereas a mouthful of gasoline is generally not a fatal dose (OTA 1989). Also, persons who have ingested methanol do not exhibit telltale symptoms (except for intoxication) for at least $10 \mathrm{~h}$, increasing the danger (Machiele 1990b). This high level of toxicity, coupled with a history of misuse, has raised strong concerns about methanol's risks to the general population if it is widely used as a fuel.

Methanol is already stored in most garages as a component of windshield washer fluid and paint stripper. It is widely sold as an industrial solvent, and many commercial carburetor cleaners are one-half methanol (Bechtold 1999). Although not as good a degreaser as gasoline, its ready availability as a fuel might plausibly lead to this type of use around the home. Although some controversy exists about the likelihood that methanol's use as a fuel leading to more home use, more exposure, and more accidental or misguided ingestion (Machiele 1990b), the possibility of this occurring appears real.

Toxicity from other means of exposure, primarily skin contact and inhalation, seems moderate. Methanol is absorbed through the skin more quickly than gasoline (OTA 1989), but momentary contact rarely causes acute problems, because methanol evaporates rapidly from the skin, limiting total absorption. Prolonged exposure to high concentrations of methanol vapors causes the same toxic effects that ingestion can, but short-term exposure to most feasible levels of vapor do not cause serious harm because of the slow rate of absorption of inhaled vapor (Machiele 1990b).

Fuel additives imparting flame color, odor, and/or taste to methanol could ameliorate concerns about its fire safety (especially because of its near-invisible flame) and difficulty of detection in drinking water supplies. However, such additives must be carefully chosen to avoid creating situations in which otherwise minor aquifer contamination creates problems with drinking water palatability. The additives should biodegrade at rates similar to those of the methanol itself, and their concentrations should be regulated to levels that provide a reasonable trade-off between the need to avoid triggering problems with drinking water when the methanol contamination is far below harmful levels and the need to provide an early warning of contamination.

\subsection{Compressed Hydrogen}

Hydrogen has been viewed as a transportation fuel primarily for use with proton-exchangemembrane (PEM) fuel cells. Although many fuel cell proponents expect that early vehicles will carry liquid fuels (such as methanol or gasoline) and produce hydrogen in onboard reactors, 
onboard hydrogen storage offers higher efficiency and zero emissions and is a more likely choice for the longer term. The fuel system examined here is hydrogen compressed to about 6,000 psi and carried in high-strength pressure vessels.

Hydrogen has long been viewed as a highly dangerous fuel, largely because of the 1937 destruction by fire of the Hindenburg airship and a variety of mishaps in the liquid-fueled rocket era. Analysis of the Hindenburg accident indicates, however, that the Hindenburg had a fragile structure covered with a highly flammable skin painted with aluminum flakes that added to the fire danger. One analysis hypothesizes that it was the airship's skin, rather than its fuel, that played the primary role in the fire (Bain 1997). In another application, the hydrogen used in rockets is intensely cold liquid hydrogen. In any case, a modern fuel-cell-powered vehicle would bear no resemblance to a 1930s airship or a liquid-fueled rocket, and its safety must be evaluated separately from that of these other vehicles.

The safety of hydrogen as a vehicle fuel remains controversial. In particular, hydrogen's potential to explode is the major concern, and some believe this characteristic makes it a highly dangerous fuel. Others who believe it is, on balance, safer than gasoline tend to focus on such characteristics as its rapid dispersion and low energy density, as well as the likelihood that its physical characteristics will demand that its fuel handling systems be designed carefully.

Hydrogen's safety advantages are as follows (Thomas 1997):

1. Low spill probability in collisions. Pressure tanks for hydrogen will be extremely strong and highly unlikely to be damaged in most collisions. The most vulnerable parts of the fuel system will be the fuel lines and pressure valves, so the ultimate safety of such systems will depend on a failsafe valve-shutoff system on the tanks.

2. More rapid dispersal when spilled than gasoline. Since hydrogen has 52 times greater buoyancy and a 12 times greater diffusion coefficient than gasoline vapor, a hydrogen spill in an unconfined area will disperse extremely quickly.

3. Relatively high LFL (4\% compared with $1 \%$ for gasoline). The rapid dispersion and mixing with air of an escaping hydrogen cloud in an unconfined space mean that its concentration in air drops below the flammability limit within seconds. Of course, if the vehicle is already on fire, the hydrogen would likely ignite. Although the advantages of higher rates of dispersion and higher LFL are reduced in a tunnel collision, hydrogen is still less likely than gasoline to be ignited by such ignition sources as fans or light fixtures.

4. If ignited, a hydrogen fire is likely to be less dangerous than a gasoline fire. Hydrogen's low emissivity reduces the risk that secondary materials will be ignited, and a hydrogen flame produces no toxic smoke (although in many fires, other materials become involved and produce smoke themselves). 
Hydrogen does pose dangers that will need to be addressed if it enters commerce as a vehicle fuel. Specifically:

1. Greater likelihood to explode upon ignition. Hydrogen is the most likely of the fuels to explode once it ignites, with a burning velocity seven times that of gasoline. An explosion can only occur if hydrogen reaches a minimum of $13 \%$ concentration in air before igniting. This concentration is quite possible in a tunnel or other confined space, although it is impossible in the open. However, a roomful of hydrogen at explosive concentrations does not contain a great deal of energy. In such an enclosed space, a hydrogen explosion would have about 20 times less energy than would an explosion involving the same volume of gasoline vapor.

2. Risk of explosion when stored under pressure. If hydrogen is stored under pressure, explosion of the fuel tank or tank or pressure gauge failure must be considered a plausible risk. Storage pressures for hydrogen are likely to be substantially higher than those for compressed natural gas $(\mathrm{CNG})$ - about 6,000 psi versus 3,000 psi for CNG. Clearly, there will be rigid guidelines for tank designs and failsafes for relief pressure valves, but problems can arise from misuse, aging, and stress from vehicle crashes, among others.

3. Invisible flame when burning. Hydrogen fires burn with an invisible flame. Unless a flame enhancer can be added (this might be difficult, because of the need to avoid poisoning the fuel cell), this represents an added danger in vehicle fires.

4. Hydrogen lacks odor. Hydrogen has no odor, so a slow leak in a garage could be particularly dangerous. If odorants could be found that would not poison the fuel cell, this problem could be mitigated, although a hydrogen detector would be a more effective solution because home garages are unoccupied most of the time. Slow leaks of other fuels, including gasoline, present similar dangers, although gasoline's strong odor is a mitigating factor.

5. Embrittlement of certain metals. Hydrogen causes embrittlement of certain metals, such as high-strength steels. This potential problem requires careful selection of materials for the fuel system, although aluminum and composites (used for the tanks) are not vulnerable to embrittlement.

6. Ignition hazard related to slow leaks. A continuous hydrogen leak (e.g., at a refueling station) has a high probability of igniting. Hydrogen has both a wide flammability range and extremely low ignition energy, making a continuous leak a more likely fire risk than a similar natural gas leak.

Emergency response guidelines put hydrogen in the higher risk category along with dimethyl ether, with a 0.5 -mi downwind evacuation for spills and 1-mi evacuation for tank and tanker fires (DOT, Transport Canada, and Secretariat of Transport and Communications, Mexico, 1996). 
Hydrogen presents none of the environmental or health problems that the other fuels do. If spilled, it immediately disperses with no environmental harm, and it is nontoxic if inhaled.

Hydrogen's lack of odor and gaseous form mean that vehicle repair shops will have to be quite careful in servicing a hydrogen vehicle's fuel system. The combination of low odor, invisibility, lack of flame color, and the potential for leaks implies the need for reliable and affordable gas-detection capability, and DOE has invested substantial development funds on gasdetection and measurement capability during the past few years. Hydrogen leak detectors are commercially available and used in food processing (hydrogenation plants), petroleum refining, and process industries. Were hydrogen to become a commercial transportation fuel, these or other designs would have to be adapted for use at service stations, repair facilities, and possibly even residential garages.

Hydrogen is widely produced and used in oil refining but is not widely sold or transported. Its limited volume in commerce means that codes and standards for handling hydrogen are limited. According to the National Hydrogen Association, however, significant work has begun on such standards, with draft standards for connectors, containers, and service stations already submitted to the International Standards Organization, and work on other standards (e.g., selfservice refueling) is under way (New Fuels and Vehicles Report 1999). Also, the National Aeronautics and Space Administration (NASA) has published a comprehensive safety standard for hydrogen (NSS 1740.16).

Progress has been made on alternative forms of hydrogen storage (e.g., storage at low pressure in metal hydrides). In particular, the weight of hydrogen stored per kilogram of storage medium has been increased, leading to hopes that low-pressure storage will be a practical alternative for future fuel cell vehicles. Such a system should be safer than a high-pressure storage system, since the potential for accidental rapid release of large quantities of hydrogen is lower. 


\section{Section 4 Infrastructure Issues Associated with Fuel Safety Concerns}

Each fuel has somewhat different safety implications, and so differences (from the baseline) must be recognized early and incorporated into the development of the new fuel supply infrastructure; otherwise, public health and safety could be adversely affected. Gasoline, as the primary motor fuel of this country for nearly a century, has a significant advantage, in terms of safety, in that the workforce associated with gasoline production and distribution is intimately familiar with its dangers, plus the storage, handling, and use "system" has the benefit of such long-term experience. Also, motor fuel workers and users have not had to pay much attention to the possibility that the fuel they are dealing with might not be gasoline (if it happened to be diesel, it would be that much safer). During the first few years following the entry of significant quantities of alternative fuels, there may be numerous safety incidents that arise because workers simply forget that the fuel they are handling is not gasoline. On the opposite side, it is perhaps conceivable that workers and users will pay a bit more attention to fuel safety issues when the fuels are new and "exotic" - but this remains to be seen.

In addition to the properties of the individual fuels, as discussed in Section 3, the likely volume of new fuels (as compared with current volumes of the same or similar chemicals handled by the existing infrastructure) and the likely rate of introduction of the new fuels will have important safety implications. Clearly, designing an appropriate fuel delivery, storage, and dispensing system and training personnel in appropriate fuel-handling techniques and incident response measures will be needed for any substantial volume of new fuel under any introduction timetable. However, if the phase-in is rapid and volumes are much larger than in existing commerce, the situation could be exacerbated. For this reason, examining alternative fuel projections under the high-market-share scenario is useful (see Section 1 for a description of the scenarios).

\subsection{Alternative Fuel Volumes Relative to Current Gasoline Volumes}

The first step in identifying infrastructure issues is evaluating the volume of alternative fuel that may enter commerce if the PNGV is successful and PNGV vehicles use alternative fuels. The high-market-share scenario postulates that " $3 \mathrm{X}$ vehicles" (PNGV vehicles obtaining three times the fuel economy of current vehicles) enter the market in 2007 and capture a $60 \%$ share of the new LDV market by 2030. A simulation of this scenario estimates that in 2020, PNGV vehicles would use about $5 \%$ of total LDV fuel in gasoline-equivalent gallons; that proportion would rise to $26 \%$ in 2030 . Note that the high efficiency of the PNGV vehicles means that total fuel use is considerably less than that which would have occurred without these vehicles. In 2030, projected LDV fuel use is only $86 \%$ of 1999 levels, rather than the $18 \%$ higher volume projected for the reference, or baseline, case defined in Section 1.

The actual physical volume of fuel moved depends, of course, on fuel energy density. Table 2 presents the energy densities of the fuels examined here. As shown in the table, shipping methanol, ethanol, and DME from storage to refueling stations will require from $50 \%$ to 
Table 2 Energy Densities of Alternative

PNGV Fuels for Light-Duty Vehicles

\begin{tabular}{|lcc|}
\hline Fuel & $\begin{array}{c}\text { Energy Density } \\
\text { Btu/gal (LHV) }\end{array}$ & $\begin{array}{c}\text { Energy Density } \\
\text { (Gasoline = 1) }\end{array}$ \\
\hline Hydrogen ${ }^{\mathrm{a}}$ & 13,000 & 0.12 \\
RFG & 113,000 & 1.00 \\
Methanol & 57,000 & 0.50 \\
Ethanol & 76,000 & 0.67 \\
DME & & \\
RFD & 68,000 & 1.60 \\
F-T Diesel $50 \%$ & 128,500 & 1.09 \\
Biodiesel B20 & 123,600 & 1.12 \\
\hline Source: Wang et al. (1998). & \\
a Storage at about 6,000 psia. & \\
b Storage at about 90 psia. &
\end{tabular}

$100 \%$ more tanker truck or rail tanker car trips than an energy-equivalent amount of gasoline, while all forms of diesel fuel would require somewhat fewer trips. The energy density of hydrogen, even under 6,000-psia storage, is too low for tanker transport. Hydrogen will either have to be moved by pipeline or manufactured at the refueling station; shipment as cryogenic (liquid) hydrogen is possible but unlikely because of the expense and energy loss.

Given these energy densities and the above projection of fuel use, the worst case, in terms of volume of fuel movement, has methanol fueling all PNGV vehicles. For this case, in 2030, methanol would represent approximately $41 \%$ of the total volume of fuel consumed by light-duty vehicles, or about $35 \%$ of the current volume of gasoline in commerce.

\subsection{Speed of Market Introduction of Alternative Fuels}

The high-market-share scenario shows a very gradual entry of alternative fuels into the light-duty market. Market entry begins in 2007, and alternative fuel consumption is only 100 million (gasoline equivalent) gallons per year (Mgal/yr) in 2010 and does not surpass $1 \mathrm{billion}$ gal/yr until 2015 and 10 billion gal/yr until 2023; the volume in 2030 is about 26 billion $\mathrm{gal} / \mathrm{yr}$ ( $26 \%$ of total light-duty vehicle fuel use). This scenario of gradual market entry seems completely compatible with historical rates of entry of technology into the light-duty vehicle marketplace. Automakers typically move a new technology into a single model, or at most a very few models, in order to gauge market acceptance and to minimize their technological risk. Despite extensive precommercial testing, automakers have experienced serious technical failures in the past (e.g., the Chevrolet Vega aluminum engine and the Oldsmobile diesel) and thus

3 Since, as noted above, hydrogen will likely be shipped by pipeline (a very safe mode) or manufactured at refueling stations. 
attempt to minimize their exposure during this initial market-entry period. Automakers generally wait a few years to gather experience with the new technology, and only then begin to deploy it throughout their model lineup. Because turnover of the fleet is slow, with an average vehicle age of about 8 yr (Davis 1998), it usually takes more than a decade from market entry for a new technology to capture a sizeable share of the total vehicle stock.

The implication here is that new transportation fuels will not "flood" the automotive fuel market. Instead, they will gradually increase their market share and total volume, thereby providing sufficient time to get the necessary safety infrastructure into place.

The gradual introduction of new transportation fuels should ease, although not eliminate, concerns about building a safety infrastructure. Although the gradual pace of introduction removes some of the urgency, it does not negate the need for a strong effort to build such an infrastructure in a timely fashion.

\subsection{Volume of Alternative Fuels Relative to Current Hazardous Materials Shipments}

In gauging the potential impact on safety infrastructure (in particular on hazardous material [hazmat] emergency response) of a partial shift away from gasoline to alternative fuels, it is useful to examine the current flow of petroleum products and other hazardous chemicals. A few key statistics are illuminating:

- In rail transport, gasoline is well down on the list of hazardous material shipments. In 1997, gasoline ranked $13^{\text {th }}$ in originations among all hazardous chemicals, with about 30,000 originations, compared with 33,000 originations for methanol and 185,000 for liquefied petroleum gas (Association of American Railroads 1998). Given the wide range of chemicals currently shipped by rail and gasoline's modest role in this shipping, substituting alternative fuels for gasoline in rail shipments does not appear to create any strain on the hazardous materials response system.

- Gasoline accounts for a large share of truck shipments of hazardous materials. In 1996, about 1.5 million tons of gasoline were shipped daily by truck, compared with about 1.5 million tons of other petroleum products and about 0.85 million tons of other hazardous materials, especially chemicals (DOT 1998). In other words, of hazardous materials shipped by truck, gasoline represents about $40 \%$.

We can combine the estimated $40 \%$ gasoline share of truck hazmat shipments with the fuel volumes developed above to estimate a potential worst-case market share of alternative fuel shipments. As noted, methanol has the lowest energy density of the selected fuels (with the exception of hydrogen, which will not be shipped by truck in gaseous form), so $100 \%$ use of methanol by $3 \mathrm{X}$ vehicles represents a worst-case scenario for volumes of truck traffic. If the difference in weights between gasoline and methanol are ignored, the worst-case scenario for truck shipment implies that in 2030, fuel methanol would represent, at most, $0.35 \times 40 \%$, or $14 \%$ of truck shipments of hazardous materials. This calculation does not take into account the likely growth in total hazardous material shipments over time. 


\subsection{Impact on Hazardous Material Emergency Response Infrastructure}

Even in the optimistic high-market-share scenario, alternative fuel volumes will grow at a gradual pace and, during the period of interest (present to 2030), will remain a moderate part of total truck shipments of hazardous materials. Therefore, the emergency response infrastructure for hazardous materials should not have difficulty in keeping pace with highway tanker transport of new fuels for $3 \mathrm{X}$ vehicles, assuming that the response infrastructure is adequate today.

The adequacy of the hazmat response infrastructure has not been carefully examined for some time. The Office of Technology Assessment published the last comprehensive review of the infrastructure (OTA 1986) in 1986. In that review, OTA identified a number of issues (training deficiencies, reporting loopholes, and some regulatory shortcomings) that raise concerns about introducing large quantities of alternative fuels. The box below lists some of the key conclusions of the OTA report.

One important OTA concern - that spills during intrastate shipment of hazardous materials did not require federal reporting — has been addressed by 62 FR 1207, which requires most intrastate shippers to comply with federal hazmat reporting rules.

The shortfalls in response training identified by OTA appear likely to have eased during the intervening 15 years. The response community has grown to about 3.2 million firefighters, police, and other responders, which is more than a $50 \%$ increase from the reported 1986 levels. The Hazardous Materials Emergency Preparedness (HMEP) Grants Program has trained an estimated 120,000-130,000 responders per year during fiscal years 1993-1995 (DOT 1998), and other training avenues are available to response team personnel. This information suggests an increase in the numbers of personnel trained to respond to hazmat emergencies.

Updating our understanding of the emergency response infrastructure for hazardous materials would be prudent before introducing large volumes of alternative fuels into the transportation system. In all likelihood, such introduction will not create major new problems for the infrastructure.
Summary of Key Conclusions of 1986 Office of Technology Assessment Report on Hazardous Materials Emergency Response Network

- There is a lack of interagency coordination for recordkeeping on accidents and releases of hazardous materials

- As of 1986, a maximum of $25 \%$ of the approximately 2 million people in the emergency response network have received "adequate training to meet a hazardous materials emergency."

- The volunteer firefighters and emergency response forces from small urban and rural areas usually have no hazardous materials training at all.

- Recently, DOT man-years devoted to hazardous material inspections have fallen.

- Second- and third-hand cargo tankers that no longer meet federal requirements may be legally operated within some states.

- The Research and Special Programs Administration (RSPA) has no complete record of the firms it regulates.

- Intrastate highway releases (note: gasoline transport is mostly intrastate) do not have to be reported to RSPA.

- Accidents involving cargo tank trucks transporting gasoline (note: gasoline represents about $49 \%$ of all hazardous materials transported by tank truck) cause more deaths and damage than all other hazardous materials accidents combined.

- Many intermodal tank containers travel on 40-ft flatbed trucks and are secured by chains - a major safety problem. 
However, the public is likely to view incidents involving new fuels with a more critical eye than "ordinary" gasoline tanker incidents. The transportation industry and the U.S. Department of Transportation (DOT) should therefore view correcting any current deficiencies in the hazmat response infrastructure as a high priority.

\subsection{Firefighting Issues for Alternative Fuels Versus Gasoline}

Vehicle fires are a common-enough occurrence - there are several hundred thousand in the United States each year (OMS 1998) - that all local fire departments must be equipped to handle them. In the United States, there are over 30,000 fire departments of all sizes; all but about 3,200 are staffed primarily by volunteers, and there are slightly over one million firefighters, three-quarters of whom are volunteers (National Fire Protection Association data, cited in Volpe National Transportation Systems Center 1998). The wide-scale introduction of new fuels implies that most or all of these fire departments and firefighters must be trained and equipped to deal with the fire and explosion hazards of these fuels.

Generally, the most effective way to fight vehicle fires is to use firefighting foams that cover and smother the fire. When fuel spillage and burning fuel are a problem, water will spread the fire because gasoline will float — and burn — on top of the water; the foams are designed to cover the surface of the burning fuel and "knock down" the fires. A number of companies (e.g., Chemguard and $3 \mathrm{M}$ ) manufacture various types of firefighting foams and the equipment to apply it. Although there are numerous types of foams to handle firefighting needs, ranging from gasoline vehicle fires to fires at refineries and chemical plants involving a wide variety of chemicals, local fire companies are most likely to carry ordinary aqueous-film-forming foams (AFFFs), which are highly effective on fires involving hydrocarbon fuels (e.g., gasoline) and relatively inexpensive. Smaller companies may carry dry chemical extinguishers, which are also effective on vehicular fires, but they require firefighters to get closer to the vehicle.

An obvious concern associated with the widespread introduction of one or more new vehicle fuels is the potential need for adjusting both the training and the equipment mix for the thousands of local fire companies that must deal with vehicle fires. Also of concern are any potential difficulties associated with introducing a degree of uncertainty into dealing with a vehicle fire because firefighters may have to determine which fuel is onboard in order to properly deal with the fire. Although specialized emergency response teams may be trained and equipped to deal with fires involving multiple chemicals and fuels, local fire companies are not.

If alcohol fuels (ethanol and/or methanol) are added to the mix of common vehicle fuels, the major impact is likely to be economic. Ordinary AFFF foams are not effective with alcohols. Because alcohols readily mix with water, the water in the fire-suppressing foam blanket formed by an AFFF foam will mix with the alcohol and the foam blanket will collapse, exposing the fuel surface to the air and allowing the fuel to burn once again. Fortunately, the need for more robust foams for industrial firefighting has resulted in the development of multipurpose foams that will work with either hydrocarbons or alcohols. For example, AR-AFFF foams include a highmolecular-weight polymer that will precipitate when the alcohol absorbs water from the foam, 
forming a membrane between the fuel and the foam, thereby maintaining fire suppression. 4 These more versatile foams can be used with standard foam-dispensing equipment. However, the foams do cost more. For example, Chemguard charges \$20/gal for standard 3\% AFFF foam and \$36/gal - almost double - for 3:3 AR-AFFF foam, which can be applied without knowing whether the target is a hydrocarbon or alcohol-fuel fire (Hopson 1998). An intermediate foam that will work on alcohol fires if used in higher concentrations - a so-called 3:6 AR-AFFF foam — provides a much less expensive alternative ( $\$ 21 / \mathrm{gal})$, but it requires that the fire company first identify the burning liquid or else use the higher concentration foam and thus pay more to fight the fire than the more versatile 3:3 foam would have cost.

The solubility of alcohol fuels is an important firefighting advantage, at least when the total volume of fuel is not large. Water flooding a small alcohol fire is effective because the alcohols will quickly be diluted to nonflammable concentrations (for methanol, less than about 20\%). By contrast, gasoline would simply float on top of the water, and flames would be more likely to spread to secondary flammables.

Local fire companies might have to make important adjustments in training and equipment if gaseous fuels were added to the mix. The added potential for explosion, particularly in the case of hydrogen, might complicate firefighting efforts. Very high standards of fuel system design and manufacture probably can be expected, and such standards should minimize these problems. However, aging of vehicles' fuel system components, perhaps with corrosion problems, and improper vehicle repair after a crash could increase vehicle vulnerability to explosions in fires.

\subsection{Maintenance and Repair of Alternative-Fuel Vehicles Versus Conventional Vehicles}

The dominance of gasoline and diesel fuel for light-duty vehicles may present a safety problem to vehicle maintenance and repair facilities, since safety precautions for alternative fuels can be somewhat different from those for the dominant fuels. This potential problem is somewhat mitigated by the reality that gasoline is highly flammable, toxic if inhaled in moderate concentrations, extremely dangerous if ingested, and damaging to skin if subject to prolonged contact. Although the other liquid alternative fuels pose varying risks related to these issues, the general precautions needed to avoid damage to persons and property (provision of excellent ventilation, control of potential ignition sources, and availability of fire suppression equipment) are similar. The few exceptions center on the explosive danger of gaseous fuels and the possible higher flammability of some alternative fuels in enclosed environments. For example, gasoline spilled in enclosed environments may present less danger than, say, methanol because the fuel vapor/air mixture quickly exceeds the upper flammability limit; however, leaks from the room would still be flammable, and exhaustion of the fuel vapors would move the air/fuel mixture

4 Note that many gasolines do contain alcohol or ethers (MTBE and ethyl tertiary butyl ether [ETBE]) that theoretically would complicate firefighting with AFFF foams. Underwriters Laboratory has found that conventional AFFF foams successfully smother fires in gasolines with up to $10 \%$ alcohol content. High concentrations of ethers pose a more difficult problem, and fire companies normally encountering such concentrations would probably already be using advanced foams. (Source: Dick Ottman, 3M Corporation, personal communication, 11/19/98.) 
through the flammable range for a time. Safety analyses of hydrogen used as a vehicle fuel have identified fuel system maintenance and repair, or repair that may inadvertently damage fuel lines, as key areas for careful safety training (Thomas 1997).

Automotive technology has been changing rapidly over the past few decades; for example, different types of fuel injection systems have been introduced, new emission controls have been developed, computer power has been added, variable valve timing and lift systems have been introduced, and many other advances have been made. These changes have required auto mechanics to undergo continuous retraining. Fortunately, retraining automotive technicians to deal with safety issues associated with alternative fuels appears to fall completely in line with this ongoing process of training for new technology.

\subsection{Storage of Alternative Fuels and Vehicles}

\subsubsection{Home Garages}

To place the potential impact of storing alternatively fueled vehicles in garages (including the small garages attached to single-family houses or townhomes) into perspective, it should be remembered that garages typically store not only vehicles fueled with highly flammable gasoline, but also paints and solvents, gasoline (in storage containers) for lawnmowers, insecticides, and pool chemicals, among others. We conclude that important new problems are likely to arise only if small leaks or spills from fuel tanks or fuel supply lines are difficult to detect (gasoline leaks clearly are easily detected because of their odor, if someone is in the garage to smell the odor) or can cause an explosive or fire potential that clearly exceeds the danger from gasoline.

The fuel most likely to cause a significant problem in vehicle storage is hydrogen, because it will be difficult to detect unless mixed with an odorant 5 and because it has significant explosive potential. There will be a need to develop a reliable, low-cost hydrogen detector for any locations that will store hydrogen vehicles. However, problems related to maintaining in-home smoke detectors may indicate that there will be problems related to maintaining hydrogen detectors. Local fire departments, for example, constantly find smoke detectors with discharged batteries, or even without batteries.

\subsubsection{Refueling Stations}

Delivery systems for dispensing alternative fuels will be tailored to the physical/chemical properties and unique qualities of each fuel. Assuming that hoses, tanks, nozzles, and other components of the storage and delivery system are designed specifically to handle the new fuel (as opposed to having been converted from gasoline use), there is no reason to anticipate any increased incidence of leaks or spills. If, however, existing equipment is converted to alternativefuel use without adequate investigation of potential materials incompatibilities or assurance that it is structurally sound, potential problems could arise. At the extreme, unless appropriate

5 The major issue with selecting an odorant (or additive to create flame luminosity, another concern with hydrogen) is the need to avoid poisoning the fuel cell stack. It may be possible to scrub out the odorant before it enters the stack, although this will add cost. 
safeguards are undertaken, events like the recent cases of MTBE contamination of aquifers from leaking underground storage tanks could be repeated with some of the alternative fuels under consideration.

\subsection{Spills and Contamination of Drinking Water Supplies}

The major components of gasoline and diesel fuel are not miscible with water, reducing considerably the danger of aquifer contamination resulting from spills of these fuels onto the land surface. For the same reason, and because gasoline and diesel fuels tend to float at the water surface, spills into surface waters can often be contained if emergency equipment arrives on the scene quickly. However, the MTBE component of gasoline, which is water soluble and has been implicated in extensive aquifer contamination through leaking gasoline storage tanks, does represent a danger to drinking water supplies in case of a spill. California is in the process of phasing out MTBE use in its gasoline supply, and conceivably other states may follow. Other gasoline components, such as benzene, toluene, and xylene, may also contaminate drinking water supplies, unless spills are cleaned up promptly.

The alternative fuels examined here present different degrees of danger to water supplies. Hydrogen and dimethyl ether should not represent a spill danger because of their gaseous form. The alcohols represent a different problem because they are soluble in water and difficult to contain in a spill; they move quickly into aquifers and spread rapidly in surface waters. Ethanol is relatively harmless in low concentrations, so it should not represent a danger to drinking water supplies. However, fuel ethanol may contain a strongly flavored denaturant to discourage people from drinking it, and this denaturant could pose a problem to drinking water supplies. Fuel methanol is dangerous in small concentrations, so a large methanol spill should represent a greater danger to drinking water supplies than the other fuels. It seems likely that, in the event of large-scale methanol fuel use, the spill response infrastructure will have to add significantly expanded capacity to monitor drinking water inlets and wells in the vicinity of spills.

\subsection{Monitoring of Safety Incidents Involving Alternative Fuels}

As discussed previously, the widespread introduction of new automotive fuels into the marketplace is likely to result in a difficult transition period as fuel users, vehicle designers, auto mechanics, firefighters, and others adjust to a range of new safety issues. One key to moving rapidly and successfully through this transition will be the network of monitoring agencies that will track safety incidents, evaluate patterns that identify safety shortcomings, and report to a range of stakeholders so that regulations get changed, people adjust their behavior, and fuel handlers and users and equipment designers improve their performance to acceptable levels. One key question is: How robust is the current system of identifying fuel safety issues, and how might it adjust to accommodate new fuels?

Transportation fuels are hazardous materials, and there are firm federal requirements for reporting hazardous materials spills during transport. Spills of gasoline and other fuels from tanker trucks and other carriers, as well as consequent fires, explosions, water contamination, or other impacts, must be reported to the Research and Special Programs Administration (RSPA) of 
DOT as a direct requirement of 49CFR171.15 and 16. 6 RSPA presumably would take the lead in evaluating the data associated with accidents and identifying important trends in fuel distribution safety.

Problems that may arise from defective vehicle design are the province of the National Highway Traffic Safety Administration (NHTSA). Within NHTSA, the Office of Defects Investigation is responsible for investigating reports of vehicle fuel system integrity problems. Information about defects should arise primarily from three sources.

First, the U.S. Fire Administration (part of the Federal Emergency Management Agency [FEMA]) runs a national fire database called the National Fire Incident Reporting System (NFIRS), a tool fire departments use to report and maintain computerized records of fires. The data are passed forward to interested agencies, with data on transportation-related fires passed on to NHTSA. The system is voluntary, but 42 states participate. The fire reports are detailed enough to provide important evidence of trends in new fuel safety, but only if the reports are diligently filed. For example, key data fields include the following:

- Area of fire origin, including engine area, running gear, wheel area, fuel tank, and fuel line.

- Item first ignited, including flammable liquid/gas, hose, hose covering, and filter.

- Type of material first ignited, including liquid propane (LP) gas, hydrogen flammable gas, gasoline, flammable or combustible liquid, or other material.

- Cause of ignition, including mechanical failure, malfunction, automatic control failure, design deficiency, installation deficiency, manufacturing deficiency, or collision.

The fields could easily be expanded to include new fuels if they were introduced in large quantities.

Second, reports of safety problems are received from NHTSA's auto safety hotline. NHTSA personnel are confident that the hotline will prove to be an excellent source of information about problems with new fuels because there are substantial positive incentives for reporting (Hart 1999):

- An NHTSA investigation that assigns blame to a manufacturer and requires a recall virtually guarantees that any losses from fuel system defects will be reimbursed.

- Private litigators against vehicle manufacturers in accident cases can gain substantial leverage from an NHTSA investigation, assuming that it identifies a system as faulty.

6 The regulations require spills to be reported if they cause fatalities, injuries requiring hospitalization, property damage over $\$ 50,000$, or closing of major transportation arteries. 
Third, vehicle accident reports will be collected by NHTSA's national database, especially in cases involving fatalities (records of fatal accidents are handled by the FARS, or Fatal Accident Reporting System, database). However, these records will show only whether a fire has occurred in the course of an accident. Crucial details about the role of vehicle fuel, integrity of fuel systems, or cause and effect are not reported in FARS records, although these details would be evaluated in case of a formal NHTSA investigation.

Fires at other stages of the fuel cycle, such as at filling stations and repair facilities, presumably would also be reported by local and state firefighting agencies through the NFIRS system.

Evaluating the adequacy of the reporting mechanisms identified above is outside the scope of this study, and we have not yet examined the capabilities and resources of incident analysis and data collecting and reporting agencies, such as NHTSA's Defects Investigations Office and RSPA. Because of the importance of incident reporting and analysis, undertaking a careful assessment of the current system of fuel safety reporting and evaluation would be prudent before widespread introduction of new fuels into the U.S. fleet. Investigating vehicle fires is costly and requires substantial expertise not readily available at the local level where most such fires would be handled. Without further evaluation, it may be prudent to assume that the reporting of such fires through NFIRS is likely to be haphazard. 


\section{Section 5 References}

Argonne National Laboratory, 1995, Chemical Management System Material Safety Data Sheet

- 13413 Methanol, submitted by J.S. Baker, Inc., Phillipsburg, N.J., Oct.

Association of American Railroads, 1998, Annual Report of Hazardous Materials Transported by Rail; Calendar Year 1997, report BOE 97-1, Bureau of Explosives, Nov.

Bain, A., 1997, "The Hindenburg Incident: Cause and Effect," keynote address at the $8^{\text {th }}$ Annual U.S Hydrogen Meeting, Alexandria, Va., March 12 (cited in Thomas 1997).

Bain, A., et al., 1998 (draft), Sourcebook for Hydrogen Applications, Hydrogen Research Institute and National Renewable Energy Laboratory, June 1.

Bechtold, R., 1999, personal communication, March.

Bisio, A., 1999, personal communication, Jan. 25.

Davis, S.C., 1998, Transportation Energy Data Book, Edition 18, ORNL-6941, Oak Ridge National Laboratory, Center for Transportation Analysis, Oak Ridge, Tenn., Sept.

DOE: U.S. Department of Energy

DOE, 1996, Annual Energy Outlook 1996, DOE/EIA-0383 (96), Energy Information Administration.

DOT: U.S. Department of Transportation

DOT, Transport Canada, and Secretariat of Transport and Communications, Mexico, 1996, 1996 North American Emergency Response Guidebook.

DOT, 1998, Hazardous Material Shipments, Office of Hazardous Material Safety, October.

DOT, 1998, Report to Congress on the Hazardous Materials Emergency Preparedness (HMEP) Grants Program, Aug.

FTA: Federal Transit Administration

FTA, 1995, Summary Assessment of the Safety, Health, Environmental and System Risks of Alternative Fuel, DOT-VNTSC-FTA-95-5, U.S. Department of Transportation and U.S.

Department of Energy, Aug.

Hart, C., 1999, National Highway Traffic Safety Administration, personal communication, Dec. 
Hopson, C., 1998, Chemguard, Inc., personal communication, Sept.

J.E. Sinor Consultants, Inc., 1997, Dimethyl Ether as a Transportation Fuel, A State-of-the-Art Survey, prepared for U.S. Department of Energy through the National Renewable Energy Laboratory, June.

Krupka, M.C., A.T. Peaslee, and H.L. Laquer, undated, Gaseous Fuel Safety Assessment for Light-Duty Automotive Vehicles, LA-9829-MS, Los Alamos National Laboratory.

Machiele, P.A., 1990a, Methanol Fuel Safety: A Comparative Study of M100, M85, Gasoline, and Diesel Fuel as Motor Vehicle Fuels, EPA-AA-SDSB-90-01, U.S. Environmental Protection Agency, Office of Mobile Sources, Nov.

Machiele, P.A., 1990b, "Methanol's Effects on Health and Safety," in Methanol as an Alternative Fuel Choice: An Assessment, W.L. Kohl (editor), Paul H. Nitze School of Advanced International Studies, Washington, D.C.

Murphy, M.J., 1992, Properties of Alternative Fuels, FTA-OH-06-0060-92-5, Battelle Memorial Institute, prepared for U.S. Department of Transportation, Federal Transit Administration, Aug.

Murphy, M.J., 1997, Motor Fuel Options for Diesel Engines: Fuel Properties and Specifications, Battelle Memorial Institute, prepared for National Renewable Energy Laboratory, Golden, Colo., Sept. 30.

Murphy, M.J., et al., 1995, Summary Assessment of the Safety, Health, Environmental and System Risks of Alternative Fuel, DOT-FTA-MA-90-7007-95-1, Battelle Memorial Institute, prepared for U.S. Department of Transportation, Aug.

Naegeli, D.W., and K.H. Childress, 1998, "Lower Explosion Limits and Compositions of Middle Distillate Fuel Vapors," Society of Automotive Engineers paper 982485.

NHTSA: National Highway Traffic Safety Administration

NHTSA, 1999, Fatal Accident Reporting System Data, on NHTSA web site (www.nhtsa.dot.gov).

New Fuels and Vehicles Report, 1999, "Hydrogen Group Eyes R\&D Priorities for Infrastructure Standards," p.16, June 24, Washington Publishers, Washington, D.C.

NRC: National Research Council

NRC, 1994, National Research Council Review of the Research Program of the Partnership for a New Generation of Vehicle First Report, National Academy Press.

OMS: Office of Mobile Sources 
OMS, 1989, Analysis of the Economic and Environmental Effects of Methanol as an Automotive Fuel, U.S. Environmental Protection Agency Special Report, Sept.

OMS, 1990, Analysis of the Economic and Environmental Effects of Ethanol as an Automotive Fuel, U.S. Environmental Protection Agency Special Report, April.

OMS, 1998, "Methanol Fuels and Fire Safety," Fact Sheet OMS-8, U.S. Environmental Protection Agency, Ann Arbor, Mich., Aug. 1994 (updated July 1998).

OTA: Office of Technology Assessment

OTA, 1986, Transportation of Hazardous Materials, OTA-SET-304, U.S. Congress, Office of Technology Assessment, U.S. Government Printing Office, Washington, D.C., July.

OTA, 1990, Replacing Gasoline: Alternative Fuels for Light-Duty Vehicles, OTA-E-364, U.S. Congress, Office of Technology Assessment, U.S. Government Printing Office, Washington, D.C., Sept.

Pitstick, M.E., 1993, unpublished information.

Thomas, C.E., 1997, Direct-Hydrogen-Fueled Proton-Exchange-Membrane Fuel Cell System for Transportation Applications: Hydrogen Vehicle Safety Report, DOE/CE/50389-502, Directed Technologies, Inc., subcontract to Ford Motor Company, prepared for U.S. Department of Energy, Office of Transportation Technologies, May.

van der Weide, J., 1980, "Safety Testing of LPG and Gas-Fueled Vehicles," Nonpetroleum Vehicular Fuels Symposium, Institute of Gas Technology, Arlington, Va., Feb. 11-13.

Volpe National Transportation Systems Center, 1998, Infrastructure Implications of NextGeneration Vehicles, Draft, U.S. Department of Transportation, Bureau of Transportation Statistics, March 31.

Wang, M., et al., 1998, Assessment of PNGV Fuels Infrastructure. Phase 2 Report: Additional Capital Needs and Fuel-Cycle Energy and Emissions Impacts, ANL/ESD-37, Argonne National Laboratory, Center for Transportation Research, Aug. 
$\Delta$ 
